\title{
The Use of Acronyms and Slang among Adolescents on Social Media
}

\author{
AinAIYAH MARIYATUS ZAKIYAH ${ }^{1}$, YUNI INDAH SARI ${ }^{2}$, DOMAS SUGRAHITA HARJA \\ SUSETYA ${ }^{3}$ \\ ${ }^{1}$ Universitas Islam Zainul Hasan, Kraksaan, Probolinggo, Indonesia \\ ainaiyahzakiyah@gmail.com \\ ${ }^{2}$ Universitas Islam Zainul Hasan, Kraksaan, Probolinggo, Indonesia \\ indahyuni43@gmail.com \\ ${ }^{3}$ Universitas Islam Zainul Hasan, Kraksaan, Probolinggo, Indonesia \\ kurniahita@gmail.com
}

\begin{abstract}
This research is related to the use of acronyms and slang by teenagers in social media such as Facebook, Instagram, and WhatsApp. In this case, this research on the use of acronyms and slang in social media aims to find out the slang terms used by teenagers on social media and also describes a slang found in social media such as Facebook, Instagram, and WhatsApp. Then, it describes the meaning of slang contained in the social media and examples of slang sentences used by teenagers everyday on social media. This research is classified as a qualitative research type because in this research it tries to examine social phenomena in an atmosphere that takes place naturally and naturally. In analyzing the data, the researcher used qualitative methods with reading and documentation techniques. After that, some data can be found in the form of utterances or words that come from interactions between adolescents on social media. The results showed that, there were 25 examples of acronyms and 25 slang terms found by researchers in social media such as Facebook, Instagram and Whatsapp.
\end{abstract}

Keywords: youth, social media, acronym, slang 


\title{
Penggunaan Akronim dan Bahasa Gaul dalam Kalangan Remaja pada Media Sosial
}

\begin{abstract}
Abstrak
Penelitian ini berkaitan dengan penggunaan akronim dan bahasa gaul oleh kalangan remaja dalam sosial media berupa facebook, instagram, dan whatsapp. Dalam hal ini, penelitian tentang penggunaan akronim dan bahasa gaul dalam sosial media ini bertujuan untuk mengetahui adanya istilah-istilah bahasa gaul yang digunakan oleh para remaja di sosial media dan juga mendeskripsikan suatu bahasa gaul yang terdapat dalam sosial media berupa facebook, instagram, dan whatsapp, mendeskripsikan adanya arti atau makna bahasa gaul yang terdapat dalam sosial media tersebut, serta mendeskripsikan contoh kalimat bahasa gaul yang digunakan oleh para remaja sehari-hari di sosial media. Penelitian ini digolongkan kepada jenis penelitian kualitatif karena dalam penelitian ini berusaha menelaah fenomena sosial dalam suasana yang berlangsung secara wajar dan alamiah. Dalam menganalisis data, peneliti menggunakan metode kualitatif dengan teknik baca dan dokumentasi. Setelahnya, dapat ditemukan beberapa data berupa ujaran atau perkataan yang berasal dari interaksi antar remaja pada sosial media. Hasil penelitian menunjukkan bahwa, terdapat 25 contoh akronim dan 25 istilah bahasa gaul yang ditemukan oleh peneliti dalam sosial media berupa facebook, instagram dan whatsapp.
\end{abstract}

Kata kunci: remaja, sosial media, akronim, bahasa gaul

\section{PENDAHULUAN}

Bahasa merupakan suatu hal yang sangat penting dalam kehidupan manusia. Sebagai makhluk sosial yang saling membutuhkan satu sama lain, manusia memerlukan bahasa dalam melakukan suatu proses interaksi. Selain itu, didalam proses interaksi tersebut, manusia juga menggunakan bahasa untuk menyampaikan suatu ide, gagasan, pendapat, perasaan dan pikiran kepada orang lain. Berkaitan dengan hal itu, Wibowo (2013, p. 33) mengemukakan pendapatnya mengenai pengertian bahasa, menurutnya bahasa adalah suatu sarana perhubungan rohani yang amat penting dalam hidup bersama. Sedangkan menurut KBBI, bahasa itu sendiri merupakan suatu sistem lambang bunyi yang arbitrer, yang digunakan oleh anggota suatu masyarakat untuk bekerja sama, berinteraksi, dan mengidentifikasikan diri.

Seperti yang sudah kita ketahui bahwa, di Indonesia pada masa ini sudah banyak yang menggunakan ragam bahasa, seperti bahasa asing atau bahasa gaul dalam kehidupan sehari-hari. Adanya penggunaan bahasa gaul tersebut selain 
disebabkan oleh berkembangnya zaman dan teknologi, penggunaan bahasa yang bervariasi ini juga disebabkan oleh pengaruh lingkungan sekitar atau pengaruh sosial. Berkaitan dengan hal itu, maka dalam hal ini sudut pandang dari segi sosiolinguistik merupakan cakupan pertama yang mendasari adanya penggunaan bahasa gaul ini, karena adanya bahasa gaul ini merupakan salah satu contoh variasi bahasa, dan variasi bahasa ini merupakan salah satu dari beberapa contoh kajian sosiolinguistik.

Menurut Fishman (dalam Wijana \& Rohmadi, 2013, p. 7), sosiolinguistik merupakan suatu disiplin ilmu yang bersifat interdisipliner yang menggarap permasalahan-permasalahan kebahasaan dalam hubungannya dengan faktor-faktor sosial, situasional, dan kulturalnya. Selain itu, dijelaskan juga bahwa sosiolinguistik adalah bidang ilmu antardisipliner yang mempelajari bahasa dalam kaitannya dengan penggunaan bahasa itu dalam masyarakat (Chaer \& Agustina, 2013, p. 2). Berdasarkan dua pemaparan para ahli tersebut, maka dapat ditarik kesimpulan bahwa, sosiolinguistik disini merupakan suatu bidang ilmu yang menganalisis tentang bahasa dalam kaitannya dengan bahasa yang digunakan dalam suatu lingkungan.

Dewasa ini kita sama-sama tahu, bahwa penggunaan bahasa gaul lebih dominan digunakan oleh para remaja. Meskipun penggunaan bahasa gaul serta penyingkatan kata ini yang sering digunakan, namun penggunaannya tidak menghilangkan penggunaan bahasa Indonesia, hanya saja, makna dan juga penggunaan bahasa Indonesia yang baik dan sopan menjadi kabur, karena tergeser oleh penggunaan bahasa gaul. Saat ini banyak di kalangan remaja yang menggunakan bahasa gaul untuk bahasa sehari-hari mereka. Tidak hanya itu, para remaja masa kini pun mulai menciptakan sendiri bahasa-bahasa gaul yang digunakan di kalangan mereka, dengan memplesetkan bahasa Indonesia.

Dikalangan remaja, penggunaan bahasa gaul tak hanya digunakan pada kehidupan sehari-hari saja, melainkan juga pada sosial media. Selain penggunaan bahasa gaul, penggunaan akronim atau penyingkatan kata pun juga sering dipakai oleh anak-anak remaja dalam sosial media. Bahkan saat ini, jika ditilik berdasarkan pengalaman penulis, rata-rata para remaja menggunakan bahasa gaul, terkadang juga menggunakan akronim ketika berinteraksi di sosial media. Maraknya penggunaan bahasa gaul ini membuat orang-orang yang bukan tergolong remaja menjadi kesulitan memahaminya. Namun, meskipun begitu, tidak dapat dipungkiri, jika lambat laun orang awam pun yang tidak tergolong remaja, 
sedikit demi sedikit dapat memahami makna dari bahasa gaul atau penyingkatan kata yang sering digunakan oleh para remaja, karena mereka sering mendengarnya.

Pada umumnya, penggunaan bahasa gaul dan penyingkatan kata ini bertujuan untuk merahasiakan isi obrolan dari sekolompok orang tertentu. Namun, seperti yang sudah dipaparkan diatas, bahwa seringnya penggunaan bahasa gaul maupun penyingkatan kata, membuat bahasa gaul ini tidak lagi menjadi rahasia, artinya bahasa gaul itu sudah populer, dan bukan hanya para remaja yang bisa menggunakan dan memahaminya, melainkan orang awam pun juga bisa. Selain itu, secara tidak langsung, banyaknya penggunaan bahasa gaul maupun penyingkatan kata ini juga dipicu oleh rasa gengsi yang ada pada diri setiap remaja, karena jika mereka tidak mengerti, tidak mengetahui, dan juga tidak menggunakan bahasa gaul, maka mereka akan dianggap kurang update atau ketinggalan jaman oleh remaja-remaja seusia mereka. Mengingat bahwa penggunaan akronim dan bahasa gaul ini lebih banyak di gunakan pada sosial media, maka dalam hal ini penggunaan akronim dan bahasa gaul pada kalangan remaja dalam sosial media ini menjadi fokus pembahasan dalam artikel ini.

Berdasarkan fokus masalah yang sudah dikemukakan di atas, dapat dipaparkan juga mengenai tujuan dari penelitian ini. Adapun tujuan dilakukannya penelitian ini adalah mencari serta menemukan makna bahasa dari penggunaan akronim dan bahasa gaul yang terdapat di kalangan remaja pada sosial media. Makna dari bahasa tersebut biasanya hanya diketahui oleh anggota kelompok tersebut saja. Selain itu, penggunaan akronim dan bahasa gaul ini seperti yang kita ketahui juga sangat berbeda dengan ejaan PUEBI dan juga kaidah-kaidah bahasa Indonesia. Oleh karena itu, perlu dilakukan analisis pada penggunaan akronim serta bahasa gaul pada kalangan remaja dalam sosial media untuk memperdalam pemahaman kita tentang penggunaan akronim serta bahasa gaul pada kalangan remaja, terutama dalam sosial media.

Berkaitan dengan hal tersebut, dalam penganalisisan data, peneliti juga menjadikan penelitian terdahulu sebagai acuan dan pijakan untuk melakukan penelitian ini. Dimana penelitian tentang penggunaan bahasa gaul juga pernah dilakukan oleh Azizah (2019) dengan artikel yang berjudul "Penggunaan Bahasa Indonesia Dan Bahasa Gaul Di Kalangan Remaja". Antara penelitian ini dan penelitian yang dilakukan oleh Auva sama-sama berfokus pada bahasa gaul dalam kalangan remaja. Namun, bedanya ada pada objek penelitiaannya. Dimana objek 
penelitian Auva ialah penggunaan bahasa gaul dalam kehidupan sehari-hari, sedangkan dalam penelitian ini, objek penelitiannya adalah penggunaan bahasa gaul pada kalangan remaja dalam sosial media.

Kedua, penelitian yang dilakukan oleh Wiriyadi, Handayani, dan Amanah, (2018) dengan artikelnya yang berjudul, "Istilah-istilah Bahasa Gaul Anak Muda di Sosmed". Antara penelitian ini dengan penelitian yang dilakukan oleh Anjaswati, sama-sama memiliki relevansinya, yaitu sama-sama meneliti tentang bahasa gaul yang ada di sosial media. Hanya saja, letak perbedaan kedua artikel ini terdapat pada objek penelitiannya. Jika objek penelitian yang dilakukan oleh Anjaswati disini adalah bahasa gaul yang terdapat pada sosial media berupa Facebook, Twitter, Blacberry Messenger, dan Whatsapp, maka objek penelitian ini adalah bahasa gaul yang terdapat pada sosial media berupa Facebook, Whatsapp, dan Instagram saja.

Ketiga, penelitian yang dilakukan oleh Arisanti (2018) dengan artikelnya yang berjudul, "Penggunaan Akronim Dan Singkatan Dalam Media Sosial Facebook Dikalangan Remaja SMA PLUS MULTAZAM". Antara penelitian ini dan penelitian yang dilakukan Yosi sama-sama berfokus pada akronim dalam media sosial. Namun, bedanya ada pada objek penelitiannya. Dimana objek penelitian yang dilakukan Yosi ialah penggunaan akronim dalam sosial media facebook saja pada kalangan remaja SMA PLUS MULTAZAM. Sedangkan dalam penelitian ini, objek penelitiannya adalah penggunaan akronim pada kalangan remaja pada sosial media Facebook, WhatsApp, dan Instagram.

Keempat, penelitian yang dilakukan oleh Noviatri (2015) dengan artikelnya yang berjudul, "Singkatan Dan Akronim Dalam Surat Kabar : Kajian Bentuk Dan Proses". Antara penelitian ini dengan penelitian yang dilakukan Noviatri samasama berfokus pada singkatan dan akronim. Namun, bedanya ada pada objek penelitiannya. Dimana objek peneltian yang dilakukan Noviatri ialah singkatan dan akronim dalam surat kabar. Sedangkan dalam penelitian ini, objek penelitiannya adalah penggunaan akronim pada kalangan remaja pada sosial media Facebook, WhatsApp, dan Instagram.

\section{METODE PENELITIAN}

Jenis pendekatan penelitian yang digunakan oleh peneliti adalah penelitian deskriptif kualitatif. Dalam penelitian ini peneliti mengamati dan melakukan analisis terhadap percakapan para remaja yang ada pada sosial media. Setelahnya, 
peneliti mendeskripsikan makna yang dari akronim dan bahasa gaul yang digunakan para remaja tersebut. Data yang diambil pada penelitian ini berupa kata-kata yang sering digunakan oleh anak remaja pada sosial media, seperti Facebook, WhatsApp, dan Instagram.

Berkaitan dengan hal itu, peneliti mengambil sumber data dari interaksi yang terjadi antara para remaja di sosial media. Mengingat bahwa penelitian ini merupakan jenis penelitian kualitatif, maka dalam penggalian data, digunakan metode observasi dengan teknik baca, dan dokumentasi. Peneliti, lewat sosial medianya mengamati interaksi para remaja di sosial media, kemudian mencatat kata demi kata yang merupakan akronim dan bahasa gaul. Dengan pengambilan data yang demikian, tentu saja memudahkan peneliti untuk melakukan penelitian ini.

\section{HASIL DAN PEMBAHASAN}

\section{Penggunaan Akronim atau Penyingkatan Kata dalam Sosial Media}

Keberagaman bahasa yang digunakan oleh masyarakat dalam berkomunikasi disebabkan oleh perkembangan di berbagai aspek kehidupan masyarakat. Perkembaangan iptek (ilmu pengetahuan dan teknologi) merapakan salah satu faktor yang mengakibatkan perkembangan bahasa semakin maju. Globalisasi menjadi faktor utama pemicu pesatnya perubahan yang terjadi dalam berbagai aspek kehidupan masyarakat, salah satunya bahasa.

Penggunaan bahasa yang beragam lebih sering digunakan oleh kalangan remaja, sehingga dalam interaksinya dalam sosial media lebih sering menggunakan akronim atau penyingkatan kata. Dalam hal ini akronim di gunakan untuk mempermudah atau mempercepat interaksi dalam sosial media, misalkan dalam chattingan dengan teman-temannya. Oleh karena itu, sedikit banyak kata akronim bermunculan dengan semakin pesatnya sosial media yang banyak bermunculan.

Akronim atau penyingkatan kata merupakan proses pemendekan yang menggabungkan huruf atau suku kata atau bagian lain yang dilafalkan maupun dituliskan sebagai kata sedikit banyak memenugi kaidah fonotaktik Indonesia. Achmad \& A (2012, p. 69) mengemukakan bahwa akronim adalah hasil pemendekan kata yang berupa kata atau dapat dilafalkan sebagai kata. Pemendekan dapat berupa pengekalan huruf-huruf pertama yang berupa pengakalan suku-suku kata, dan juga berupa gabungan leksem yang bisa secara 
tidak beraturan. Berikut peneliti paparkan salah satu contoh analisis data yang telah dilakukan.

J : :Kamu sudah belajar untuk ulangan hari ini, Kim?"

K :" Ah iya, aku samsek belum belajar masih."

Berdasarkan kata samsek merupakan bentuk akronim dari 'sama sekali'. Pemendekan dengan pengekalan tiga huruf pertama pada suku kata pertama dan pengekalan tiga huruf pertama pada suku kata kedua.

Berikut ini pemaparan dari akronim pada kosakata yaang digunakan remaja pada sosial media.

Tabel 1.1 Akronim yang Digunakan Remaja pada Sosial Media

\begin{tabular}{|c|c|c|c|c|}
\hline No. & Kosakata & Arti & Contoh kalimat & Sumber \\
\hline 1. & Arema & Arek Maron & "Arema dilawan." & WhatsApp \\
\hline 2. & Bomat & Bodo Amat & $\begin{array}{l}\text { "Bomat gue sama Sela, } \\
\text { dibantuin malah marah- } \\
\text { marah." }\end{array}$ & Instagram \\
\hline 3. & Camer & Calon Mertua & $\begin{array}{l}\text { "Aku tadi ketemu } \\
\text { camermu di mall." }\end{array}$ & WhatsApp \\
\hline 4. & Cecan & Cewek Cantik & $\begin{array}{l}\text { "Eh, tadi dikelas gue ada } \\
\text { cecan." }\end{array}$ & WhatsApp \\
\hline 5. & Cinlok & Cinta Lokasi & $\begin{array}{ll}\text { "Aliando sama } & \text { Nabila } \\
\text { cinlok, guys!" } & \end{array}$ & Facebook \\
\hline 6. & Cogan & Cowok Ganteng & $\begin{array}{l}\text { "Kalian tahu gak, ketua } \\
\text { komunitas pencinta alam } \\
\text { ternyata cogan." }\end{array}$ & WhatsApp \\
\hline 7. & Duren & Duda Keren & $\begin{array}{l}\text { "Kapan cerai, Je? Dah jadi } \\
\text { duren sekarang... haha." }\end{array}$ & Instagram \\
\hline 8. & Galfok & Gagal Fokus & $\begin{array}{l}\text { "Maaf tadi pas dikelas } \\
\text { sering galfok aku." }\end{array}$ & WhatsApp \\
\hline 9. & Gaptek & Gagal IPTEK & $\begin{array}{l}\text { "Parah kamu, jaman } \\
\text { sekarang masih gaptek." }\end{array}$ & Facebook \\
\hline 10. & Gatot & Gagal Total & $\begin{array}{l}\text { "Prank ultah si andin } \\
\text { gatot, gara-gara hujan." }\end{array}$ & WhatsApp \\
\hline 11. & Jadul & Jaman Dulu & "Sepatunya Jadul..." & Instagram \\
\hline 12. & Jones & Jomblo Ngenes & $\begin{array}{l}\text { "Dasar jones banyak } \\
\text { gaya.... just kidding, Rei." }\end{array}$ & Instagram \\
\hline 13. & Kamsek & $\begin{array}{l}\text { Kampungan } \\
\text { Sekali }\end{array}$ & $\begin{array}{l}\text { "Lihat gak tadi, } \begin{array}{r}\text { Sela } \\
\text { kamsek }\end{array} \text { banget } \\
\text { tingkahnya, } \\
\text { marah-marah dijalan." }\end{array}$ & Instagram \\
\hline 14. & Lola & Loading Lama & $\begin{array}{l}\text { "Kita lagi bahas apa, } \\
\text { kamu jawabnya apa... } \\
\text { dasar lola." }\end{array}$ & WhatsApp \\
\hline 15. & Mabar & Main Bareng & $\begin{array}{l}\text { "Yuk, mabar langsung } \\
\text { login." }\end{array}$ & Instagram \\
\hline & Mager & Males Gerak & "Mager banget aku, & WhatsApp \\
\hline
\end{tabular}




\begin{tabular}{|c|c|c|c|c|}
\hline 16. & & & $\begin{array}{lr}\text { panas-panas } & \text { begini } \\
\text { keluar, gimana } & \text { nanti } \\
\text { sore?" }\end{array}$ & \\
\hline 17. & Malming & Malam Minggu & $\begin{array}{l}\text { "Pas malming kemaren, } \\
\text { aku nonton." }\end{array}$ & Facebook \\
\hline 18. & Mupeng & Muka Pengen & $\begin{array}{l}\text { "Muka kamu tadi } \\
\text { kelihatan mupeng banget, } \\
\text { pas diajak jalan sama } \\
\text { Leo." }\end{array}$ & WhatsApp \\
\hline 19. & Nobar & Nonton Bareng & $\begin{array}{l}\text { "Yuk, malming nobar film } \\
\text { yang lagi booming." }\end{array}$ & WhatsApp \\
\hline 20. & Omdo & Omong Doang & $\begin{array}{l}\text { "Janji tuh, ditepatin } \\
\text { bukan cuman omdo saja } \\
\text { dikedepanin." }\end{array}$ & Instagram \\
\hline 21. & Orgil & Orang Gila & $\begin{array}{l}\text { "Hati-hati kalau lewat } \\
\text { jalan kusuma, ada orgil } \\
\text { suka ngamuk." }\end{array}$ & Facebook \\
\hline 22. & Salting & Salah Tingkah & $\begin{array}{l}\text { "Aku mau cerita, tadi Gia } \\
\text { salting waktu disapa } \\
\text { sama Ken." }\end{array}$ & Instagram \\
\hline 23. & Telmi & Telat Mikir & $\begin{array}{l}\text { "Sudah selesai } \quad \text { tadi } \\
\text { pembahasannya, kamu } \\
\text { sih telmi." }\end{array}$ & Facebook \\
\hline 24. & Warkop & Warung Kopi & $\begin{array}{l}\text { "Sekarang kumpul di } \\
\text { warkop sebelah." }\end{array}$ & WhatsApp \\
\hline 25. & Warteg & Warung Tegal & $\begin{array}{l}\text { "Tadi aku ketemu Deli lagi } \\
\text { makan di warteg depan." }\end{array}$ & WhatsApp \\
\hline
\end{tabular}

\section{Penggunaan Bahasa Gaul dalam Media Sosial}

Dari tahun ke tahun, zaman semakin berkembang, begitupun dengan teknologi. Salah satu teknologi yang bisa dikatakan sangat popular di era globalisasi ini adalah sosial media. Sosial media merupakan perkembangan modern dari teknologi-teknologi berbasis web baru berbasis internet. Dengan adanya sosial media ini, semua orang dapat dengan mudah untuk berinteraksi, berkomunikasi, berpartisipasi, saling berbagi informasi, dan membentuk sebuah jaringan secara online, sehingga dapat menyebar luaskan konten mereka sendiri. Adanya sosial media menjadi salah satu sarana yang dapat memudahkan semua orang untuk melakukan sesuatu. Meskipun pada dasarnya, kebanyakan pengguna sosial media adalah anak remaja, namun, seiring berjalannya waktu, orang tua pun juga bisa menggunakan sosial media.

Namun, kita semua tahu, bahwa yang lebih dominan aktif di sosial media seperti, Facebook, Instagram, WhatsApp, dan lain sebagainya adalah anak remaja. Berkaitan dengan hal tersebut, lewat sosial media ini lah para remaja ini berinteraksi dengan gaya mereka sendiri. Gaya yang dimaksud disini bukan 
tentang fashion, melainkan gaya bahasa mereka. Penggunaan bahasa gaul pada kalangan remaja ini merupakan hal yang sudah lumrah. Bahkan pada masa ini, mereka juga sudah bisa memodifikasi bahasa Indonesia menjadi bahasa gaul versi mereka.

Tidak banyak orang tahu, bahwa sebenarnya bahasa yang digunakan oleh para remaja yang biasa mereka sebut sebagai bahasa trend atau bahasa gaul tersebut merupakan bahasa sehari-hari yang sering digunakan oleh masyarakat pada umumnya, tetapi kosakata yang digunakan sudah dimodifikasi atau dirubah misalnya, salah satu hurufnya dibolak-balik, kata-katanya cukup disingkat, dan masih banyak cara mereka memodifikasinya. Dari bahasa yang digunakan para remaja ini, mesti ada sejumlah kosakata yang dapat kita pahami, tetapi juga ada sebagian kosakata yang tidak kita pahami maknanya.

Bahasa gaul tidaklah sama dengan bahasa biasanya. Bahasa gaul pun berbeda dari bahasa Indonesia pada umumnya. Menurut Mulyana (dalam Suleman \& Islamiyah, 2018, p. 2), awal mula terciptanya bahasa gaul yang terkesan aneh dan rumit ini tentunya tidak terlepas dari perkembangan sosial media. Pesatnya perkembangan jumlah pengguna bahasa gaul ini menunjukan semakin akrabnya para remaja Indonesia dengan dunia teknologi, utamanya internet. Selain itu, munculnya bahasa gaul ini juga menunjukkan adanya perkembangan zaman yang begitu dinamis, karena suatu bahasa harus menyesuaikan dengan masyarakat penggunanya agar tetap eksis.

Seperti yang sudah dikatakan sebelumnya, dalam analisis penggunaan akronim dan bahasa gaul dalam sosial media, peneliti juga menggunakan sarana sosial media untuk mengumpulkan data-data. Setelah menganalisis bahasa gaul pada sosial media, peneliti menemukan beberapa jenis bahasa gaul serta bahasa asing yang digunakan oleh para remaja dalam sosial media yang bersumber dari facebook, instagram, dan WhatsApp.

Tabel 1.2 Bahasa Gaul yang Digunakan Remaja pada Sosial Media

\begin{tabular}{|c|l|l|l|l|}
\hline No. & Bahasa Gaul & \multicolumn{1}{|c|}{ Contoh Kalimat } & Makna & Sumber \\
\hline 1. & Kerad & $\begin{array}{l}\text { "Bocil jangan sok } \\
\text { kerad, deh!" }\end{array}$ & Keras & Facebook \\
\hline 2. & Meninggoy & $\begin{array}{l}\text { "Liat cogan tuh, } \\
\text { rasanya mau } \\
\text { meninggoy, aaa..." }\end{array}$ & Meninggal & WhatsApp \\
\hline 3. & Depresot & $\begin{array}{l}\text { "Sumpah, tugas-tugas } \\
\text { ini buat aku depresot." }\end{array}$ & Depresi & WhatsApp \\
\hline
\end{tabular}




\begin{tabular}{|c|c|c|c|c|}
\hline 4. & Membagongkan & $\begin{array}{l}\text { "Maksudnya gimana } \\
\text { sih? Membagongkan." }\end{array}$ & Membingungkan & Instagram \\
\hline 5. & Solimi & $\begin{array}{l}\text { "Heh! Jan solimi ya, } \\
\text { kamu." }\end{array}$ & Dzolim & WhatsApp \\
\hline 6. & Yaps & "Yups, itu punyaku." & Iya & WhatsApp \\
\hline 7. & Sabi & $\begin{array}{l}\text { "Yang merasa cantik, } \\
\text { sabi lah send WA." }\end{array}$ & Bisa & Facebook \\
\hline 8. & Cangtip & $\begin{array}{l}\text { "Woy lah, itu Lesty } \\
\text { cangtip banget." }\end{array}$ & Cantik & Facebook \\
\hline 9. & Mangsud & "Ha? Mangsud?" & Maksud & Facebook \\
\hline 10. & Mengsad & "Plis lah. Mengsad ini." & Sedih & Instagram \\
\hline 11. & Beud & $\begin{array}{l}\text { "Ini tugas banyak beud } \\
\text { lah." }\end{array}$ & Banget & WhatsApp \\
\hline 12. & Kang & $\begin{array}{l}\text { "Ini nih, Kang bully di } \\
\text { sosmed." }\end{array}$ & Tukang & Facebook \\
\hline 13. & Gelay & $\begin{array}{l}\text { "Ih, gak mau... gak } \\
\text { suka, gelay..." }\end{array}$ & Geli & Facebook \\
\hline 14. & Zheyenk & $\begin{array}{l}\text { "Iyya, Zheyenk. } \\
\text { Tenang aja." }\end{array}$ & Sayang & WhatsApp \\
\hline 15. & Kuy & "Kuy lah, gaskeun." & Yuk & WhatsApp \\
\hline 16. & Wangsap & $\begin{array}{l}\text { "“P! Bagi nomor } \\
\text { wangsap, dong." }\end{array}$ & WhatsApp & Facebook \\
\hline 17. & Santuy & $\begin{array}{lll}\text { "Santuy, } & \text { Sis. } & \text { Pasti } \\
\text { selesai." } & & \end{array}$ & Santai & WhatsApp \\
\hline 18. & Halu & $\begin{array}{l}\text { "Halu aja dulu, punya } \\
\text { cogan." }\end{array}$ & Halusinasi & Instagram \\
\hline 19. & Bapack-bapack & $\begin{array}{l}\text { "Kumpulan bapack- } \\
\text { bapack tik-tok,nih." }\end{array}$ & Bapak-bapak & Instagram \\
\hline 20. & Hqq & $\begin{array}{l}\text { "Definisi nyaman yang } \\
\text { hqq." }\end{array}$ & Hakiki & Instagram \\
\hline 21. & Lucknut & $\begin{array}{l}\text { "Sumpah, temen } \\
\text { lucknut ini memang." }\end{array}$ & Laknat & WhatsApp \\
\hline 22. & Gemoy & $\begin{array}{l}\text { "Gemoy banget sih, ni } \\
\text { cowok." }\end{array}$ & Gemas & Facebook \\
\hline 23. & Gosah & $\begin{array}{ll}\text { "Gosah } & \text { dipikirin. } \\
\text { Rileks aja." } & \end{array}$ & Gak Usah & WhatsApp \\
\hline 24. & Kiyutt & $\begin{array}{l}\text { "A... sumpah! Foto- } \\
\text { fotonya kiyutt..." }\end{array}$ & Cute & Facebook \\
\hline 25. & $\begin{array}{l}\text { Negara } \\
\text { flower }\end{array}$ & $\begin{array}{l}\text { "Ini nih, salah satu } \\
\text { bukti kalau Indonesia } \\
\text { adalah Negara ber- } \\
\text { flower." }\end{array}$ & $\begin{array}{l}\text { Negara } \\
\text { Berkembang }\end{array}$ & Facebook \\
\hline
\end{tabular}

\section{SIMPULAN}

Sosial media merupakan salah satu teknologi yang digunakan oleh orangorang untuk berkomunikasi. Baik tua, maupun muda, mereka sama-sama berlomba-lomba dalam menggunakan sosial media untuk kebutuhan mereka. Seiring perkembangan zaman, penggunaan sosial media pun berkembang. Dewasa ini kita menyadari bahwa adanya sosial media ini juga mempengaruhi para remaja 
dari segi penggunaan bahasa mereka.Bahasa yang dimaksud disini adalah bahasa gaul, atau bahasa asing yang kini sering atau bahkan bisa dikatakan popular dalam kalangan remaja.

Remaja yang aktif menggunakan sosial media memiliki kosa kata yang beragam jika dibandingkan dengan remaja yang tidak terlalu aktif dalam menggunakan sosial media. Penggunaan akronim dan bahasa gaul pada remaja di pengaruhi oleh beberapa faktor yaitu kecerdasan, lingkungan dan status sosial. Lingkungan sosial sangat berperan penting dalam pemerolehan bahssa gaul dan akronim. Lingkup pertemanan sebaya adalah bagian penting dari lingkungan sosial yang mempengaruhi penggunaan dan pembentukan kosakata baru, sehingga sering digunakan untuk mempersingkat waktu atau sebagai gaya. Adanya penggunaan akronim dan penggunaa bahasa gaul disini sudah menjadi istilahistilah baru yang disepakati oleh suatu kelompok tertentu, khususnya kalangan remaja. Penggunaan bahasa gaul dan akronim ini sering digunakan agar orang lain diluar kelompok peretemanan remaja tidak memahami makna kata yang diujarkan atau dituliskan.

Adanya penggunaan akronim dan bahsa gaul dalam kalangan remaja pada sosial media ini merupakan suatu topik yang menarik utuk dikaji, karena akronim atau penyingkatan kata, serta bahasa gaul disini sangat berbeda dalam kaidahkaidah bahasa Indonesia, baik itu dari segi penulisan kata, pelafalannya, atau segi maknanya. Berkaitan dengan hal itu, maka didalam penelitian ini ditemukan kurang lebih 25 penggunaan akronim dan 25 bahasa gaul yang digunakan oleh para remaja dalam sosial media berupa Facebook, WhatsApp dan Instagram.

\section{UCAPAN TERIMA KASIH}

Penelitian ini dilakukan dengan baik karena bantuan dari berbagai pihak, untuk itu kami menyampaikan beribu-ribu ucapan terima kasih kepada seluruh pihak yang telah berkontribusi dalam penelitian ini. Ucapan terimakasih yang pertama kami sampaikan kepada Bapak dan Ibu dosen yang sudah mendukung serta membimbing kami sehingga mampu menyelesaikan artikel ini. Tak lupa pula, ucapan terima kasih yang kedua kami ucapkan kepada tim redaksi Jurnal RADIANT yang telah bersedia menampung serta memperbaiki kesalahan atau kekurangan yang ada dalam penelitian kami. 


\section{DAFTAR PUSTAKA}

Achmad, \& A, A. (2012). Linguistik Umum. Jakarta: Erlangga.

Arisanti, Y. L. (2018). Penggunaan Akronim dan Singkatan dalam Media Sosial (Jejaring Sosial Facebook di Kalangan Remaja SMA Plus Multazam). Literasi: Jurnal Penelitian Bahasa dan Sastra Indonesia serta Pembelajarannya, 2(2). https:/ / doi.org/http://dx.doi.org/10.25157/literasi.v2i2.1351

Azizah, A. R. (2019). Penggunaan Bahasa Indonesia dan Bahasa Gaul di Kalangan Remaja. Skripta: Jurnal Pembelajaran Bahasa Dan Sastra Indonesia, 5(2), 3339. https: / / doi.org/https:// doi.org/10.31316/skripta.v5i2.424

Chaer, A., \& Agustina, L. (2013). Sosiolinguistik: Perkenalan Awal. Jakarta: Rineka Cipta.

Noviatri, N. (2015). Singkatan dan Akronim dalam Surat Kabar: Kajian Bentuk dan Proses. Arbitrer, 2(1), 28-43. Retrieved from

http://arbitrer.fib.unand.ac.id/index.php/arbitrer/article/view/13/12

Suleman, J., \& Islamiyah, E. P. N. (2018). Dampak Penggunaan Bahasa Gaul di Kalangan Remaja Terhadap Bahasa Indonesia. SENASBASA: Seminar Nasional Bahasa dan Sastra Indonesia, 2-5. Retrieved from http://researchreport.umm.ac.id/index.php/SENASBASA/article/view/2232/2217

Wibowo, W. (2013). Manajemen Bahasa. Jakarta: Gramedia.

Wijana, I. D. P., \& Rohmadi, M. (2013). Sosiolinguistik Kajian Teori dan Analisis. Yogyakarta: Pustaka Pelajar.

Wiriyadi, A. S., Handayani, R. P., \& Amanah, N. S. (2018). Istilah-Istilah Bahasa Gaul Anak Muda Di Sosmed. SENASBASA: Seminar Nasional Bahasa Dan Sastra Indonesia, 42-47. Retrieved from http://researchreport.umm.ac.id/index.php/SENASBASA/article/view/2218/2205 